\title{
DNA Polymerase- $\beta$ Is Expressed Early in Neurons of Alzheimer's Disease Brain and Is Loaded into DNA Replication Forks in Neurons Challenged with $\beta$-Amyloid
}

\author{
Agata Copani, ${ }^{1,3}$ Jeroen J. M. Hoozemans, ${ }^{6}$ Filippo Caraci, ${ }^{1}$ Marco Calafiore, ${ }^{1}$ Elise S. Van Haastert, ${ }^{6}$ Robert Veerhuis, \\ Annemieke J. M. Rozemuller, ${ }^{6}$ Eleonora Aronica, ${ }^{6}$ Maria Angela Sortino, ${ }^{2}$ and Ferdinando Nicoletti ${ }^{4,5}$ \\ Departments of ${ }^{1}$ Pharmaceutical Sciences and ${ }^{2}$ Experimental and Clinical Pharmacology, University of Catania, 95125 Catania, Italy, ${ }^{3}$ Institute of \\ Biostructure and Bioimaging, National Research Council, 95125 Catania, Italy, ${ }^{4}$ Department of Human Physiology and Pharmacology, University of Rome \\ "La Sapienza," 00185 Rome, Italy, ${ }^{5}$ Mediterranean Neurological Institute Neuromed, 86077 Pozzilli, Italy, ${ }^{6}$ Department of Neuropathology, Academic \\ Medical Center, University of Amsterdam, 1105 AZ Amsterdam, The Netherlands, and 7Departments of Psychiatry, Pathology, and Clinical Chemistry and \\ Alzheimer Center, Vrije University Medical Center, 1007 MB Amsterdam, The Netherlands
}

Cultured neurons exposed to synthetic $\beta$-amyloid $(\mathrm{A} \beta)$ fragments reenter the cell cycle and initiate a pathway of DNA replication that involves the repair enzyme DNA polymerase- $\beta$ (DNA pol- $\beta$ ) before undergoing apoptotic death. In this study, by performing coimmunoprecipitation experiments on cross-linked nucleoprotein fragments from A $\beta$-treated neurons, we demonstrate that DNA pol- $\beta$ coimmunoprecipitates with cell division cycle 45 (Cdc45) and with DNA primase in short nucleoprotein fragments. This indicates that DNA pol $\beta$ is loaded into neuronal DNA replication forks after $A \beta$ treatment. In response to $A \beta$ the canonical DNA-synthesizing enzyme DNA pol- $\delta$ also was loaded into neuronal replication forks, but at later times than DNA pol- $\beta$. Methoxyamine, an inhibitor of the apurinic/ apyrimidinic endonuclease that allows for the recruitment of DNA pol- $\beta$ during the process of base excision repair (BER), failed to affect coimmunoprecipitation between DNA pol- $\beta$ and Cdc 45 , indicating that DNA pol- $\beta$ loading to the replication forks is independent of DNA breaks. However, methoxyamine reduced DNA replication and ensuing apoptosis in neurons exposed to $\mathrm{A} \beta$, suggesting that an efficient BER process allows DNA replication to proceed up to the threshold for death.

These data demonstrate that DNA pol- $\beta$ is an essential component of the DNA replication machinery in A $\beta$-treated neurons and additionally support the hypothesis of a close association of cell cycle events with neuronal death in Alzheimer's disease (AD). Accordingly, by investigating the neuronal expression of DNA pol- $\beta$, along with phosphorylated retinoblastoma protein and neurofibrillary changes in AD brain, we show an early involvement of DNA pol- $\beta$ in the pathogenesis of AD.

Key words: $\beta$-amyloid; DNA polymerase- $\beta$; APE-1/Ref-1; methoxyamine; DNA replication; DNA repair

\section{Introduction}

$\beta$-Amyloid $(\mathrm{A} \beta)$, which is thought to play a causal role in Alzheimer's disease (AD) (Hardy and Selkoe, 2002), activates an unscheduled cell cycle in neurons by inducing the expression of the typical molecular repertoire necessary for the $\mathrm{G}_{1} / \mathrm{S}$ phase transition (Copani et al., 1999; Giovanni et al., 1999, 2000). This is similar to what has been found in other models of neuronal death both in vitro and in vivo (for review, see Capani et al., 2001; Becker and Bonnie, 2004; Herrup et al., 2004). What is observed additionally in neurons exposed to $A \beta$ is that they enter the $S$ phase before they die by apoptosis (Copani et al., 1999). DNA replication also is detected by the fluorescent in situ hybridization tech-

Received April 14, 2006; revised Aug. 25, 2006; accepted Aug. 29, 2006.

This work was supported by the Ministry of Instruction, the University and Research Project of National Interest 2005 (A.C.), and Hersenstichting Nederland (J.J.M.H.). We thank Elisa Trovato-Salinaro for technical assistance.

Correspondence should be addressed to Dr. Agata Copani, Department of Pharmaceutical Sciences, University of Catania, Viale A. Doria 6, 95125 Catania, Italy. E-mail: acopani@katamail.com.

DOI:10.1523/JNEUROSCI.2793-06.2006

Copyright $\odot 2006$ Society for Neuroscience ～0270-6474/06/2610949-09\$15.00/0 nique in neurons in vulnerable regions of the $\mathrm{AD}$ brain (Yang et al., 2001). In cultured neurons challenged with $A \beta$ it is the DNA replication machinery itself that triggers cell death (Copani et al., 2002). In neurons $A \beta$ induces the 449 and p58 subunits of primase, the enzyme that initiates de novo DNA synthesis at the replication forks. However, as opposed to commonly dividing cells, neurons that enter the $S$ phase in response to $A \beta$ fail to express DNA polymerase- $\alpha$ (DNA pol- $\alpha$ ), which is essential for the canonical DNA synthesis (Copani et al., 2002). Neurons instead overexpress DNA pol- $\beta$, a DNA repair enzyme that only occasionally performs de novo DNA synthesis, e.g., during DNA endoreduplication of trophoblast cells (Siegel and Kalf, 1982) or when it substitutes for DNA polymerase I in bacteria (Sweasy and Loeb, 1992). DNA pol- $\beta$ has a causal role in $A \beta$-induced DNA replication and neuronal death, as shown by knocking down the enzyme or inhibiting its activity with dideoxycytidine (DDC) (Copani et al., 2002). As opposed to DNA pol- $\beta$ inhibition, DNA pol- $\delta$ inhibition by aphidicolin reduces $A \beta$-induced DNA replication, but not neuronal apoptosis. Thus DNA pol- $\delta$, which is expressed constitutively by cultured neurons and additionally is 
not induced by $\mathrm{A} \beta$, may contribute to de novo DNA synthesis in a way that is dissociated from neuronal death (Copani et al., 2002).

In this study we address whether the "pathological" DNA synthesis in $\mathrm{A} \beta$-treated neurons starts at typical replication forks or is associated with processes of DNA damage and repair and whether, and in which sequence, the two enzymes that support DNA synthesis in $\mathrm{A} \beta$-treated neurons, i.e., DNA pol- $\beta$ and DNA pol- $\delta$, are loaded into replication forks. We report that DNA pol- $\beta$ and DNA pol- $\delta$ are loaded sequentially at the replication forks of neurons challenged with $A \beta$. Whereas DNA pol- $\beta$ loading occurs independently of base excision repair (BER) processes, the recruitment of DNA pol- $\delta$ relies in part on a process of BER performed by apurinic/apyrimidinic endonuclease-1/redox factor-1 (APE-1/Ref-1) and, likely, by DNA pol- $\beta$ itself. This BER process is found to contribute to the overall DNA synthesis and apoptotic death induced by $\mathrm{A} \beta$ and is suggested to trigger the signal for neuronal death before the loading of DNA pol- $\delta$.

Finally, we asked how DNA pol- $\beta$ expression relates to neuronal pathology in $\mathrm{AD}$ brain. We demonstrate a positive correlation between DNA pol- $\beta$ and phosphorylated retinoblastoma protein ( $\mathrm{ppRb}$ ) immunoreactivity levels in neurons of $\mathrm{AD}$ brain, thus substantiating the hypothesis that DNA pol- $\beta$ is involved causally in AD neurodegeneration.

\section{Materials and Methods}

Cell culture. Cultures of pure cortical neurons were obtained from embryonic day 15 rat embryos according to a well established method that allows for the growth of a virtually pure neuronal population (Copani et al., 1999). $\mathrm{A} \beta_{25-35}$, purchased from Bachem (Bubendorf, Switzerland), was applied to mature neuronal cultures between 8 and $12 \mathrm{~d}$ in vitro. $\mathrm{A} \beta$ was used to a final concentration of $25 \mu \mathrm{M}$ in the presence of the ionotropic glutamate receptor antagonists MK-801 [10 $\mu \mathrm{M}$; (+)-5-methyl10,11-dihydro- ${ }^{5} \mathrm{H}$-dibenzo[a,d]cyclohepten-5,10-imine maleate] and DNQX $(30 \mu \mathrm{M})$ to avoid the contribution of endogenous glutamate to the overall neurotoxicity. In some experiments methoxyamine (15 mM) was added $30 \mathrm{~min}$ before $\mathrm{A} \beta$, whereas aphidicolin $(8 \mu \mathrm{g} / \mathrm{ml})$, DDC $(80$ $\mu \mathrm{M})$, or $\mathrm{H}_{2} \mathrm{O}_{2}(0.1-100 \mu \mathrm{M})$ was coapplied with $\mathrm{A} \beta$.

Cross-linking of chromatin proteins and preparation of DNA/protein fragments. We adopted the protocol described by Göhring and Fackelmayer (1997), slightly modified as follows. Culture dishes were crosslinked with $1 \%$ formaldehyde for $10 \mathrm{~min}$ at room temperature (RT), followed by a quenching of the cross-linking reaction with $125 \mathrm{~mm}$ glycine for an additional 5 min at RT. Cross-linked cells were washed with cold PBS, scraped off the dishes, and centrifuged at $750 \times g$ for $5 \mathrm{~min}$. The pellet was resuspended in three packet cell volumes (pcv) of RSB buffer [containing the following (in mM): 10 Tris- $\mathrm{HCl}, 10 \mathrm{NaCl}, 3 \mathrm{MgCl}_{2}, \mathrm{pH} 8$ ] and homogenized by 25 strokes in a Dounce homogenizer. Nuclei were collected by centrifugation at $750 \times g$ for $10 \mathrm{~min}$, and unbound proteins (e.g., protein that had not been cross-linked) were extracted in modified buffer $\mathrm{E}$ [containing the following (in $\mathrm{mM}$ ): 10 Tris- $\mathrm{HCl}, 10 \mathrm{Na}_{2} \mathrm{~S}_{2} \mathrm{O}_{5}, 1$ EDTA-KOH plus $1 \mathrm{~m} \mathrm{NaCl}, 0.1 \% \mathrm{NP}-40$, and Sigma (Milan, Italy) mixture protease inhibitors diluted 1:100]. Cross-linked nuclear proteins were collected by centrifugation at $750 \times g$ for $10 \mathrm{~min}$. Collected nuclei were resuspended in $0.5 \mathrm{pcr}$ lysis buffer $(50 \mathrm{~mm}$ Tris/ $\mathrm{HCl}, 10 \mathrm{~mm}$ EDTA, $1 \%$ SDS, and mixture protease inhibitors) and maintained at $4^{\circ} \mathrm{C}$ for 10 min. Then the DNA/protein complex was sheared by sonication to give fragments with DNA of different base pair lengths. A total sonication time of $3 \mathrm{~min} / \mathrm{sample}$ with a Vibra Cell (Sonics \& Materials, Danbury, CT) with output control setting 5 resulted in DNA fragment sizes of $\sim 0.3$ $\mathrm{kb}$. Fragment sizes of an average length of $1.0 \mathrm{~kb}$ were obtained with a total sonication time of $1 \mathrm{~min} / \mathrm{sample}$. Debris was cleared by minifuge centrifugation at maximum speed for $10 \mathrm{~min}$ at $4^{\circ} \mathrm{C}$. An aliquot of the supernatant containing the DNA/protein complexes was used to check the size distribution of DNA fragments on $1.2 \%$ agarose gel.

Immunoprecipitation of DNA/protein complexes and Western blot anal- ysis. DNA/protein complexes were diluted to $200 \mu \mathrm{g} / \mathrm{ml}$ in chromatin immunoprecipitation buffer [containing the following (in $\mathrm{mM}$ ): 1.2 EDTA, 16.7 Tris- $\mathrm{HCl}, 167 \mathrm{NaCl}, \mathrm{pH} 8.1$, plus $0.01 \%$ SDS, $1.1 \%$ Triton $\mathrm{X}-100]$ and immunoprecipitated with the following antibodies: 10 $\mu \mathrm{g} / \mathrm{mg}$ protein lysate of rabbit anti-DNA primase ( $\mathrm{p} 49$; NeoMarkers, Fremont, CA) or $10 \mu \mathrm{g} / \mathrm{mg}$ protein lysate of goat anti-cell division cycle 45 (anti-Cdc45; Santa Cruz Biotechnology, Santa Cruz, CA). Immunoprecipitation was performed by incubating the lysates for $2 \mathrm{~h}$ at $4^{\circ} \mathrm{C}$; then $20 \mu$ l of either protein A-agarose (for the primase antibody) or protein $\mathrm{G}$ Plus-agarose (for the Cdc45 antibody) was added, and samples were incubated overnight at $4^{\circ} \mathrm{C}$ on a rotating device. Pellets were collected by centrifugation at $1000 \times \mathrm{g}$ for $5 \mathrm{~min}$ at $4^{\circ} \mathrm{C}$ and washed three times in PBS. After a final wash the pellets were resuspended in $25 \mu \mathrm{l}$ of $1 \times$ electrophoresis sample buffer and boiled for $3 \mathrm{~min}$. Western blot analysis was performed as previously described (Copani et al., 1999, 2002), using the following antibodies: mouse anti-DNA polymerase- $\beta(2 \mu \mathrm{g} / \mathrm{ml}$; NeoMarkers), goat anti-DNA polymerase- $\delta(2 \mu \mathrm{g} / \mathrm{ml}$; Santa Cruz Biotechnology), goat anti-Cdc45 (2 $\mu \mathrm{g} / \mathrm{ml}$; Santa Cruz Biotechnology), rabbit anti-APE-1/Ref-1 $(0.5 \mu \mathrm{g} / \mathrm{ml}$; Santa Cruz Biotechnology).

Fluorescence-activated cell sorting analysis for simultaneous assessment of $S$ phase and apoptosis. Neurons were processed for fluorescenceactivated cell sorting (FACS) analysis as described previously (Copani et al., 1999, 2002). Briefly, neurons were harvested by incubation with $0.25 \%$ trypsin for $3 \mathrm{~min}$ and collected by low-speed centrifugation after the addition of $50 \%$ fetal calf serum. Neuronal pellets were fixed in $70 \%$ ethanol and treated for $1 \mathrm{~h}$ at $37^{\circ} \mathrm{C}$ with RNase $(100 \mu \mathrm{g} / \mathrm{ml})$ before propidium iodide staining $(50 \mu \mathrm{g} / \mathrm{ml}$ for $30 \mathrm{~min})$. DNA content and ploidy were assessed by using a Coulter Elite flow cytometer (Beckman Coulter, Milan, Italy), and cell cycle distribution profiles were analyzed with the Multicycle AV software program. Apoptotic neurons were scored from the area of hypoploid DNA preceding the $G_{0} / G_{1}$ DNA peak.

Immunofluorescent staining for microtubule-associated protein-2. Suspended cells, prepared as described above, were permeabilized with $0.01 \%$ Triton X-100 and then stained for $1 \mathrm{~h}$ at $4^{\circ} \mathrm{C}$ with a mouse monoclonal antibody to microtubule-associated protein-2 (MAP-2) (1:750 dilution; Millipore, Bedford, MA). After a washing, a FITC-conjugated secondary antibody (1:200 dilution; Santa Cruz Biotechnology) was added for $30 \mathrm{~min}$.

MTT assay. Cells were incubated with MTT $(0.9 \mathrm{mg} / \mathrm{ml}$ final concentration; Sigma) for $2 \mathrm{~h}$ at $37^{\circ} \mathrm{C}$. A solubilization solution containing $20 \%$ SDS then was added for an additional $1 \mathrm{~h}$, and formazan production was evaluated in a microplate reader (absorbance, $560 \mathrm{~nm}$ ).

Postmortem brain tissue. Human brain specimens of $\mathrm{AD}$ and nondemented control cases were obtained at autopsy with a short postmortem interval (The Netherlands Brain Bank, Amsterdam, The Netherlands). Clinical diagnosis was defined according to the Diagnostic and Statistical Manual of Mental Disorders, edition III revised, criteria; the severity of dementia was evaluated according to the Global Deterioration Scale of Reisberg (GDS) (Reisberg et al., 1982). Neuropathological evaluation was performed on formalin-fixed, paraffin-embedded tissue from different sites, including the frontal cortex (F2), temporal pole cortex, parietal cortex (superior and inferior lobule), occipital pole cortex, and the hippocampus (essentially CA1 and entorhinal area of the parahippocampal gyrus). The distribution and the density of neurofibrillary tangles were determined in Bodian-stained sections, whereas senile plaques were stained with the methenamine silver method (Yamaguchi et al., 1990). Staging of AD was evaluated according to Braak and Braak (1995). Demographic characteristics of the cases used in this study are shown in Table 1.

DNA pol- $\beta$ immunohistochemistry. For the immunohistochemical stainings formalin-fixed $(4 \%, 24 \mathrm{~h})$ paraffin-embedded tissue from the midtemporal cortex was used. Sections ( $5 \mu$ m thick) were mounted on Superfrost/Plus tissue slides (Menzel-Gläser, Braunschweig, Germany) and deparaffinized. Subsequently, the sections were immersed in $0.3 \%$ $\mathrm{H}_{2} \mathrm{O}_{2}$ in methanol for 20 min to quench endogenous peroxidase activity and treated in $10 \mathrm{~mm}$ citrate buffer, $\mathrm{pH} 6.0$, heated by autoclave for antigen retrieval.

Serum and antibodies were diluted in PBS. Sections were preincubated for 30 min with normal goat serum (Dako, Glostrup, Denmark). Mouse 
Table 1. Summary of the cases used in this study

\begin{tabular}{|c|c|c|c|c|c|c|}
\hline Clinical diagnosis & Case number & Gender & Age & PMI (h) & Braak score & Type of analysis \\
\hline \multirow[t]{22}{*}{ Control } & 1 & $\mathrm{~F}$ & 64 & 8 & 0 & WB/IHC \\
\hline & 2 & $M$ & 70 & 5 & 0 & IHC \\
\hline & 3 & $M$ & 53 & 14 & 0 & $\mathrm{IHC}$ \\
\hline & 4 & $M$ & 73 & 24 & 0 & WB/IHC \\
\hline & 5 & $\mathrm{~F}$ & 41 & 7 & 0 & WB \\
\hline & 6 & $\mathrm{~F}$ & 61 & 7 & 0 & WB \\
\hline & 7 & $M$ & 78 & 5 & I & WB/IHC \\
\hline & 8 & $\mathrm{~F}$ & 72 & 6 & I & WB/IHC \\
\hline & 9 & $M$ & 98 & 8 & I & WB/IHC \\
\hline & 10 & $F$ & 78 & 6 & I & $\mathrm{IHC}$ \\
\hline & 11 & $F$ & 82 & 6 & I & WB \\
\hline & 12 & $F$ & 76 & 5 & I & WB \\
\hline & 13 & M & 82 & 6 & I & WB \\
\hline & 14 & $\mathrm{~F}$ & 82 & 8 & I & WB \\
\hline & 15 & $\mathrm{~F}$ & 94 & 3 & $\|$ & $\mathrm{IHC}$ \\
\hline & 16 & $F$ & 88 & 5 & ॥ & $\mathrm{IHC}$ \\
\hline & 17 & M & 82 & 13 & II & $\mathrm{IHC}$ \\
\hline & 18 & $\mathrm{~F}$ & 77 & 9 & II & $\mathrm{IHC}$ \\
\hline & 19 & $\mathrm{~F}$ & 83 & 7 & $\|$ & WB/IHC \\
\hline & 20 & $M$ & 87 & 8 & \| & WB \\
\hline & 21 & $\mathrm{~F}$ & 97 & 7 & III & $\mathrm{IHC}$ \\
\hline & 22 & $M$ & 81 & 6 & III & WB \\
\hline Average & & & 77.2 & 7.9 & & \\
\hline \multirow[t]{23}{*}{$A D$} & 23 & $\mathrm{~F}$ & 91 & 9 & III & $\mathrm{IHC}$ \\
\hline & 24 & $\mathrm{~F}$ & 89 & 4 & III & $\mathrm{IHC}$ \\
\hline & 25 & $\mathrm{~F}$ & 87 & 4 & III & WB/IHC \\
\hline & 26 & $\mathrm{~F}$ & 93 & 6 & IV & $\mathrm{IHC}$ \\
\hline & 27 & $\mathrm{~F}$ & 83 & 5 & IV & $\mathrm{IHC}$ \\
\hline & 28 & $\mathrm{~F}$ & 86 & 5 & IV & $\mathrm{IHC}$ \\
\hline & 29 & $\mathrm{~F}$ & 91 & 4 & IV & $\mathrm{IHC}$ \\
\hline & 30 & $\mathrm{~F}$ & 84 & 10 & IV & WB/IHC \\
\hline & 31 & $\mathrm{~F}$ & 84 & 4 & IV & WB \\
\hline & 32 & $\mathrm{~F}$ & 88 & 12 & IV & WB \\
\hline & 33 & $\mathrm{~F}$ & 83 & 4 & V & $\mathrm{IHC}$ \\
\hline & 34 & M & 67 & 5 & V & $\mathrm{IHC}$ \\
\hline & 35 & $\mathrm{~F}$ & 82 & 4 & V & $\mathrm{IHC}$ \\
\hline & 36 & M & 78 & 8 & V & $\mathrm{IHC}$ \\
\hline & 37 & $\mathrm{~F}$ & 69 & 7 & V & WB \\
\hline & 38 & $\mathrm{~F}$ & 87 & 6 & V & WB \\
\hline & 39 & $\mathrm{~F}$ & 91 & 5 & V & WB \\
\hline & 40 & $\mathrm{~F}$ & 76 & 6 & $\mathrm{VI}$ & $\mathrm{IHC}$ \\
\hline & 41 & $\mathrm{~F}$ & 80 & 5 & $\mathrm{VI}$ & $\mathrm{IHC}$ \\
\hline & 42 & $F$ & 65 & 5 & VI & $\mathrm{IHC}$ \\
\hline & 43 & M & 80 & 4 & VI & $\mathrm{IHC}$ \\
\hline & 44 & $\mathrm{~F}$ & 70 & 4 & VI & WB/IHC \\
\hline & 45 & $\mathrm{~F}$ & 78 & 4 & VI & WB \\
\hline Average & & & 81.8 & 5.6 & & \\
\hline
\end{tabular}

All of the material was from The Netherlands Brain Bank (Amsterdam, The Netherlands). PMI, Postmortem interva (time in hours between death and autopsy); age, age at death; WB, Western blot analysis; IHC, immunohistochemistry; $F$, female; $M$, male.

monoclonal anti-DNA pol- $\beta$ (clone 18S) was obtained from NeoMarkers, diluted 1:25, and incubated overnight at $4^{\circ} \mathrm{C}$. As a secondary step PowerVision poly-HRP-anti-mouse/rabbit/rat IgG (Immunologic, Klinipath, Duiven, The Netherlands) was used. Detection was performed with the use of diaminobenzidine (DAB) as a substrate for HRP. Nuclei were counterstained with hematoxylin, and the sections were mounted with Entellan (Merck, Darmstadt, Germany).

Double immunohistochemistry. To determine the colocalization of DNA pol- $\beta$ with neurofibrillary changes, $A \beta$ deposits, and cell cycle proteins, we performed double-immunostaining experiments. Paraffin sections were deparaffinized, immersed in $0.3 \% \mathrm{H}_{2} \mathrm{O}_{2}$ in methanol to quench endogenous peroxidase activity, and treated in $10 \mathrm{~mm}$ citrate buffer, $\mathrm{pH}$ 6.0, heated by autoclave for antigen retrieval. After incubation with Protein Block (Dako) the sections were incubated with the first primary antibody, mouse monoclonal anti-DNA pol- $\beta$, for $60 \mathrm{~min}$ at RT. As a secondary step PowerVision poly HRP-anti-mouse/rabbit/rat IgG was used, followed by color development with DAB. Sections were rinsed in water and incubated with rabbit anti-phosphoserine $\mathrm{pRb}\left(\mathrm{pSer}^{795}\right.$; 1:25 dilution; Cell Signaling Technology, Beverly, MA) for 60 min at RT. Swine anti-rabbit conjugated to biotin (1:300 dilution; Dako) and streptavidin conjugated to alkaline phosphatase (1:100 dilution; Southern Biotechnology Associates, Birmingham, AL) were used as second and third steps, respectively, followed by color development with Liquid Permanent Red Substrate (Dako). Sections were mounted in Aquamount (BDH Chemicals, Poole, UK).

Double immunolabeling with two mouse monoclonal antibodies was performed as follows. After immunodetection of DNA pol- $\beta$ with PowerVision poly HRP-anti-mouse/rabbit/rat IgG as a secondary step and color development with $\mathrm{DAB}$, the sections were treated with an additional antigen retrieval step (citrate buffer heated by autoclave for 10 $\mathrm{min}$ ). This step removes the unbound first primary antibodies and inactivates the HRP enzyme activity of the first secondary step. After incubation with Protein Block the sections were incubated for $60 \mathrm{~min}$ at RT with mouse monoclonal AT8 antibody (1:400 dilution), recognizing the phosphorylated $\mathrm{Ser}^{202}$ residue of the tau protein (Innogenetics, Ghent, Belgium), or mouse monoclonal 4G8 (1:400 dilution), recognizing amino acids $17-24$ of $A \beta$ (Chemicon, Hampshire, UK). After being washed, the sections were incubated for $60 \mathrm{~min}$ with rabbit anti-mouse conjugated to biotin (1:200 dilution; Dako), followed by incubation with streptavidin conjugated to alkaline phosphatase (30 min; 1:20 dilution; Southern Biotechnology Associates). Color was developed via Liquid Permanent Red Substrate, nuclei were counterstained with hematoxylin, and the sections were mounted in Aquamount. In control stainings no cross-reactions were observed between the first and second immunohistochemical incubations (supplemental Fig. 1, available at www.jneurosci.org as supplemental material).

DNA pol- $\beta$ Western blotting. Brain tissue was lysed in buffer [containing the following (in mM): 100 Tris, $\mathrm{pH} 7.5,100 \mathrm{KCl}, 1$ EDTA plus $1 \%$ $\mathrm{NP}-40$ and protease inhibitor mixture (Roche, Indianapolis, IN)] at $4^{\circ} \mathrm{C}$ for $30 \mathrm{~min}$ and centrifuged at $12,000 \times \mathrm{g}$ at $4^{\circ} \mathrm{C}$ for $10 \mathrm{~min}$ to obtain total soluble cell lysate. Protein concentration was determined accordingly with a Bio-Rad (Hercules, CA) protein assay that used bovine serum albumin as a standard. Equal amounts of proteins were separated on 10 or $12 \%$ polyacrylamide gel and blotted onto Immobilon membranes (Millipore, Billerica, MA). After blocking nonspecific binding with 5\% nonfat dry milk in PBS with $0.1 \%$ Tween 20 for $2 \mathrm{~h}$, we incubated the membranes overnight at $4^{\circ} \mathrm{C}$ with mouse monoclonal anti-DNA pol- $\beta$ (1:500; NeoMarkers), goat polyclonal anti DNA pol- $\beta$ (1:500 dilution) obtained from Santa Cruz Biotechnology, and nonphosphorylated eukaryotic elongation factor 2 (eEF2; Cell Signaling Technology). As a secondary step rabbit anti-goat conjugated with HRP (1:2000 dilution; DakoCytomation) was used. The blots were visualized by using LumiLightPLUS Western blotting substrate (Roche) and a LAS-3000 luminescent image analyzer (Fuji Photo Film, Düsseldorf, Germany). Western blot data were evaluated and quantified by the Advanced Image Data Analyzer (AIDA; version 3.45.039; Raytest, Straubenhardt, Germany).

\section{Results \\ DNA pol- $\boldsymbol{\beta}$ is loaded into DNA replication forks in cultured cortical neurons challenged with $\mathrm{A} \boldsymbol{\beta}$}

For the preparation of cell cultures we used a method that allows us to obtain a pure population of cortical neurons entirely devoid of astrocytes or other dividing cells, as shown by cell cycle analysis and immunostaining for the neuronal marker MAP-2 and the astrocyte marker glial fibrillary acidic protein (GFAP) (Copani et al., 1999). The homogeneity of the cell population and the absence of dividing cells were assessed in representative cultures for each experiment by cell cycle analysis (cultures containing $>0.5 \%$ of cells in S phase were discarded) and flow cytometric analysis of MAP-2 immunostaining (supplemental Fig. 2, available at www.jneurosci.org as supplemental material). Pure cultures of rat cortical neurons were challenged with $25 \mu \mathrm{M}$ of $\mathrm{A} \beta_{25-35}$. 
A

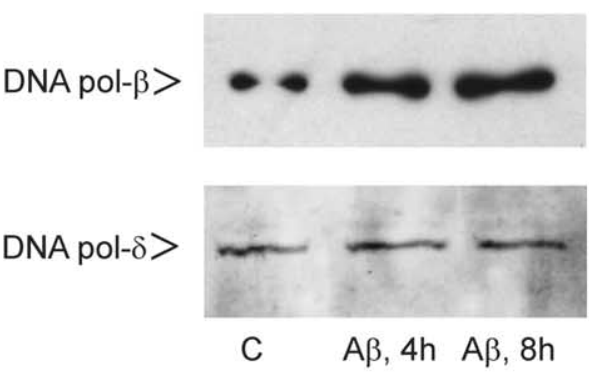

B

\section{Ip p49 primase}

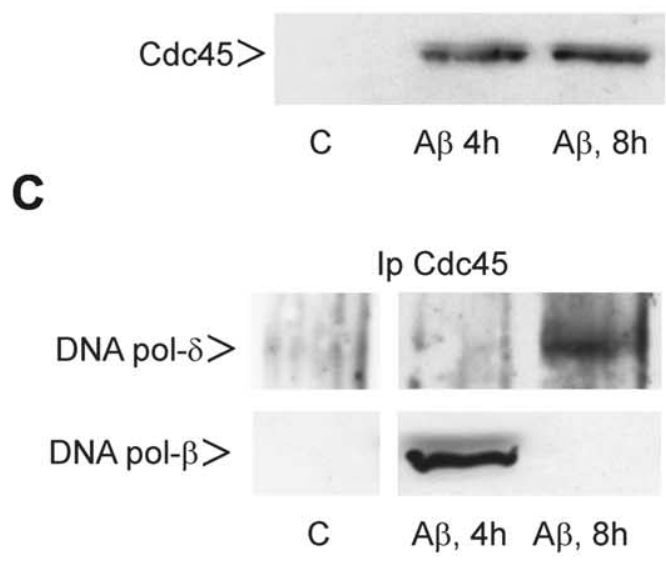

D

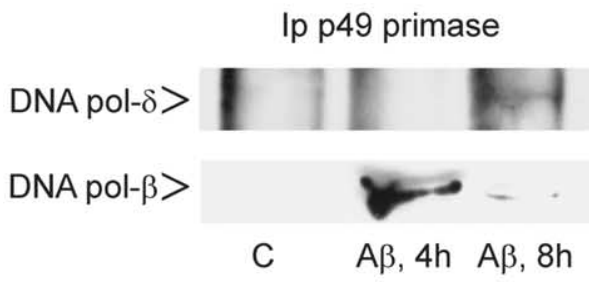

E
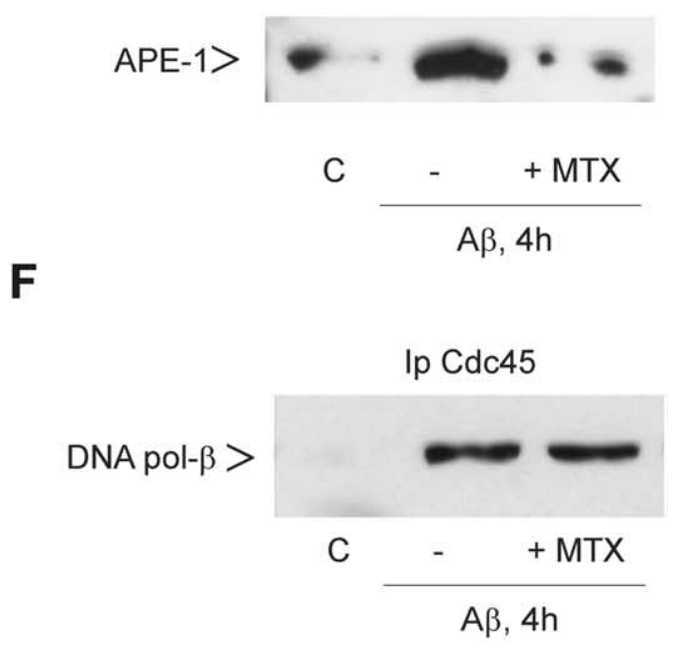

DNA pol- $\delta>$

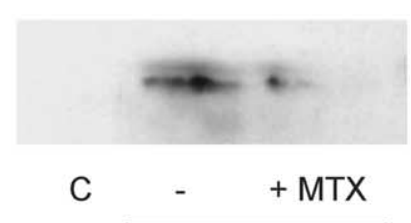

$A \beta, 8 h$
This treatment led to the activation of cell cycle, followed by apoptotic death, as expected (Copani et al., 1999) (see below). Western blot analysis in total cell extracts confirmed that $\mathrm{A} \beta$ increased the expression of DNA pol- $\beta$ in neurons at both 4 and $8 \mathrm{~h}$, whereas it did not affect the levels of DNA pol- $\delta$ (Fig. $1 A$ ). We then examined whether DNA pol- $\beta$ and pol- $\delta$ were loaded into DNA replication forks in neurons exposed to $\mathrm{A} \beta$. As a marker for typical DNA replication forks, we selected Cdc45, which is loaded on licensed origins and is known to recruit the DNA pol- $\alpha$ primase (Aparicio et al., 1999; Mimura et al., 2000; Pollok et al., 2003). We performed coimmunoprecipitation experiments on cross-linked nucleoprotein fragments at 4 or $8 \mathrm{~h}$ after neuronal exposure to $\mathrm{A} \beta$. Cdc 45 was coimmunoprecipitated with the $\mathrm{p} 49$ subunit of primase in extracts from cultures treated with $A \beta$, but not in extracts from control cultures (Fig. $1 B$ ), suggesting that Cdc45 and DNA primase associate in the replication forks of $\mathrm{A} \beta$-treated neurons as commonly observed in dividing cells (Pollok et al., 2003). DNA pol- $\beta$ coimmunoprecipitated with both Cdc 45 and the p 49 subunit of primase after $4 \mathrm{~h}$ of exposure to $\mathrm{A} \beta$, but barely was detected after $8 \mathrm{~h}$ (Fig. 1C,D). Pol- $\delta$ could be detected in Cdc45 or p49 immunoprecipitates only after $8 \mathrm{~h}$ of exposure to $A \beta$, when pol- $\beta$ was no longer detectable (Fig. $1 C, D$ ). Another difference between pol- $\beta$ and pol- $\delta$ was that the latter could be detected only in immunoprecipitates from large-sized nucleoprotein fragments (1000 bp), whereas the former also could be detected in smaller-sized fragments (300 bp) (data not shown). This suggests that pol- $\delta$ is loaded at a greater distance from the replication origin than pol- $\beta$. To exclude that pol- $\beta$, which is an established DNA repair enzyme, associates fortuitously with Cdc45 because of the proximity of a DNA strand break, we performed coimmunoprecipitation experiments in cultures treated with $A \beta$ in the presence of $15 \mathrm{~mm}$ methoxyamine. Methoxyamine is a specific inhibitor of APE- $1 /$ Ref- 1 , the enzyme that allows for the recruitment of DNA pol- $\beta$ during the process of BER (Heim et al., 2000). Treatment with A $\beta$ substantially increased the amount of APE-1 present in nucleoprotein extracts, and this effect was abolished by methoxyamine (Fig. $1 E)$. Coimmunoprecipitation between pol- $\beta$ and $\mathrm{Cdc} 45$ was not affected by methoxyamine (Fig. $1 F$ ), indicating that the loading of pol- $\beta$ to the replication forks is independent of DNA breaks. In contrast, APE-1 blockade with methoxyamine reduced the extent of pol- $\delta$ coimmunoprecipitated with Cdc 45 (Fig. $1 F$ ), suggesting that the loading of pol- $\delta$ at the replication forks partially requires an efficient APE-1 activity. We assessed S phase and apoptotic death in cultures treated with methoxyamine or with the pol- $\beta$ inhibitor DDC $(80 \mu \mathrm{M})$ or the pol- $\delta$ inhibitor aphidicolin $(8$ $\mu \mathrm{g} / \mathrm{ml}$ ) for comparison. As expected, DDC combined with A $\beta$ for $24 \mathrm{~h}$ mostly reduced both $\mathrm{S}$ phase and apoptosis in neurons,

\section{$\leftarrow$}

Figure 1. DNA pol- $\beta$ loading at replication forks in $A \beta$-treated neurons. $A$, Representative immunoblots of DNA pol- $\beta$ and DNA pol- $\delta$ in total protein extracts from cultured cortical neurons challenged with $25 \mu \mathrm{MA} \beta_{25-35}$ for 4 or $8 \mathrm{~h}(A \beta, 4 \mathrm{~h} ; A \beta, 8 \mathrm{~h})$. $\boldsymbol{B}$, Immunoprecipitation of 300 bp-sized nucleoprotein fragments with anti-primase antibody and blotting with $C \mathrm{C}(45$ specific antibody in controls (indicated as $C$ ) and A $\beta$-treated neurons. $C, D$, Also shown is immunoprecipitation of $1000 \mathrm{bp}$-sized nucleoprotein fragments with anti-Cdc45 antibody (C) or anti-primase antibody (D) and blotting with either DNA pol- $\beta$-specific or DNA pol- $\delta$-specific antibodies. $\boldsymbol{E}$, Representative immunoblot of APE-1 in $1000 \mathrm{bp}$-sized nucleoprotein fragments from neurons challenged with $A \beta$ for $4 \mathrm{~h}$ both in the absence $(-)$ and in the presence $(+)$ of 15 mм methoxyamine (MTX). $\boldsymbol{F}$, Immunoprecipitation of $1000 \mathrm{bp}$-sized nucleoprotein fragments with anti-Cdc45 antibody and blotting with either DNA pol- $\beta$-specific or DNA pol- $\delta$-specific antibodies. Nucleoproteins were obtained from neurons challenged with $A \beta$ for 4 or $8 \mathrm{~h}$ both in the absence $(-)$ and in the presence $(+)$ of 15 mM MTX. 
A

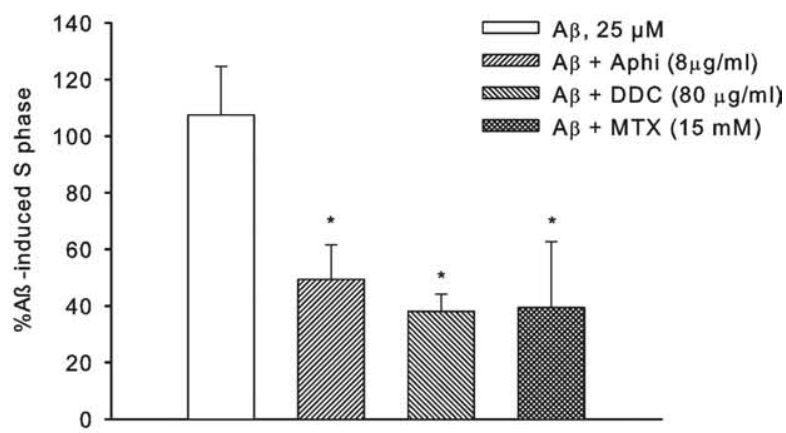

B

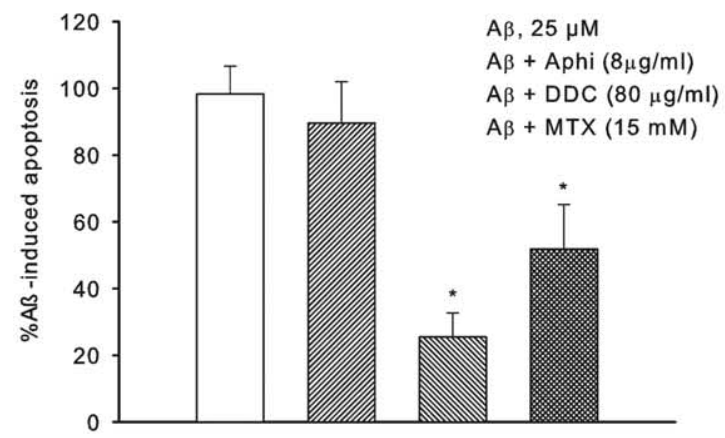

C

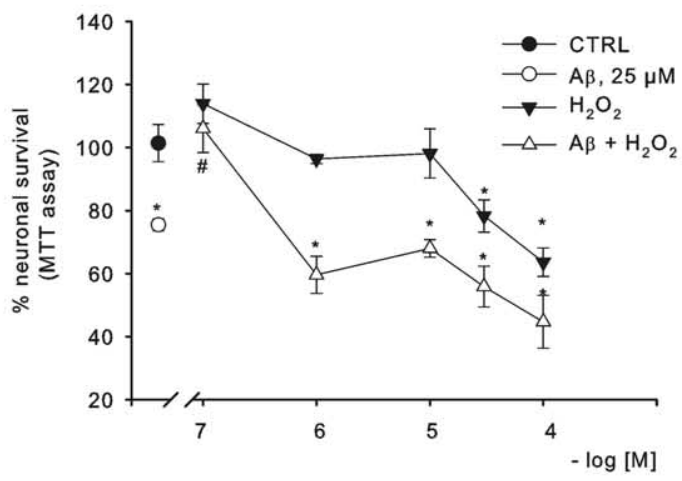

D

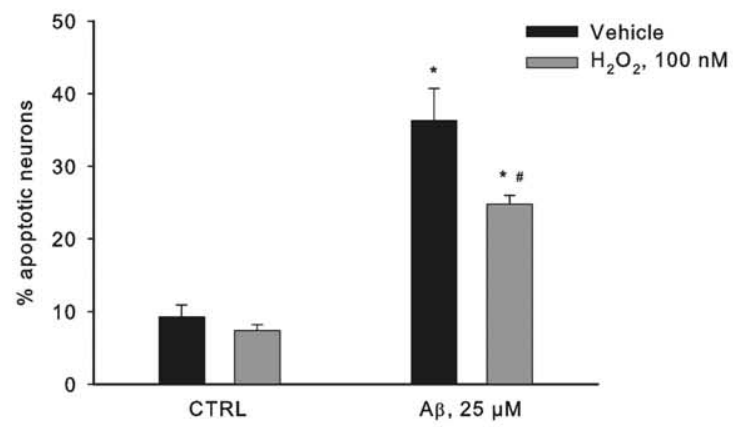

$\mathbf{E}$

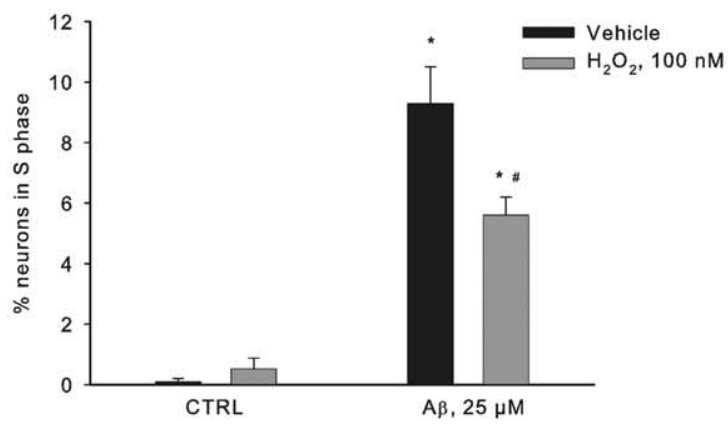

whereas aphidicolin reduced $\mathrm{S}$ phase, but not apoptotic death (Fig. 2A, $B$ ). Surprisingly, methoxyamine behaved like DDC in reducing both $S$ phase and apoptosis (Fig. $2 A, B$ ), although it did not affect the loading of pol- $\beta$ at the replication forks. Because a major consequence of methoxyamine treatment is an insufficient DNA repair by APE-1, we attempted to mimic the effect of methoxyamine by producing DNA damage to an extent that was not sufficient to cause cell death but could lead to the saturation of APE-1. Cultures were treated with increasing concentrations of hydrogen peroxide (from 0.1 to $100 \mu \mathrm{M}$ ) combined or not with $\mathrm{A} \beta$. Low concentrations of hydrogen peroxide (100 nM), which were not toxic by themselves, completely protected cortical neurons against $\mathrm{A} \beta$ toxicity, as assessed by the MTT assay or cytofluorimetric analysis of hypoploid DNA (Fig. 2C,D). Hydrogen peroxide at $100 \mathrm{~nm}$ also reduced the percentage of neurons duplicating the DNA in response to $\mathrm{A} \beta$ (Fig. $2 E$ ). Higher concentrations of hydrogen peroxide ( 10 or $100 \mu \mathrm{M}$ ) produced additive effects with $\mathrm{A} \beta$ on neuronal death (Fig. $2 C$ ).

\section{Expression of DNA pol- $\beta$ in the AD brain}

Initial Western blot analysis of DNA pol- $\beta$ expression was performed by testing two different anti-DNA pol- $\beta$ antibodies (i.e., a mouse monoclonal antibody from Neomarkers and a goat polyclonal antibody from Santa Cruz Biotechnology) in parallel samples. Both antibodies revealed an intense DNA pol- $\beta$ band at the expected molecular size $(39 \mathrm{kDa})$ in extracts from human testes used as positive controls, although the polyclonal antibody showed a number of additional bands of different molecular size (Fig. $3 A$ ). In brain samples the signal produced by the monoclonal antibody was highly specific but weak (Fig. $3 A$ ). For this reason we have used the polyclonal antibody for Western blot analysis. DNA pol- $\beta$ levels were assessed in autoptic brain specimens from 23 subjects among those listed in Table 1. DNA pol- $\beta$ expression levels were quantified and normalized for the expression of eEF $2 \alpha$, which behaves as a housekeeping protein in human brain samples (Hoozemans et al., 2005). Control and AD cases were grouped according to the Braak score (0, I/II, III/IV, and V/VI) (Fig. $3 C$ ). Expression of DNA pol- $\beta$ in cortical samples progressively increased from Braak score 0 to Braak score III/IV. In samples with Braak score V/VI the DNA pol- $\beta$ levels were remarkably lower when compared with samples with Braak score III/IV (Fig. 3A-C).

For immunohistochemical detection of DNA pol- $\beta$ we used the monoclonal antibody, which, in the testis seminiferous epithelium, specifically labeled the nuclei of spermatids (Fig. 4A, B). A specific nuclear staining also was found in neurons from control and $\mathrm{AD}$ temporal cortex (Fig. 4C-F). In nondemented controls with low Braak stages neuronal staining was observed

$\leftarrow$

Figure 2. Methoxyamine and low concentration hydrogen peroxide prevent $A \beta$-induced neuronal $S$ phase and apoptosis. $A$, Protection by methoxyamine (MTX), aphidicolin (Aphi), and $D D C$ against $A \beta$-induced apoptosis. Neurons were exposed to $25 \mu \mathrm{MA} \beta_{25-35}$ for $18 \mathrm{~h}$; $S$ phase $(\boldsymbol{A})$ and apoptosis $(\boldsymbol{B})$ were scored by FACS analysis. Values are the means \pm SEM of 10 determinations; ${ }^{*} p<0.05$ [one-way ANOVA and Fisher's least significant difference (LSD)] versus $A \beta$ alone. $C$, Protection by hydrogen peroxide $\left(\mathrm{H}_{2} \mathrm{O}_{2}\right)$ against $A \beta$-induced degeneration. Neurons were exposed to $25 \mu \mathrm{mA} \beta_{25-35}$ for $24 \mathrm{~h}$. Values are expressed as a percentage of neuronal survival (quantified by MTT assay) and were calculated by four determinations; ${ }^{*} p<0.05$ versus control (CTRL) and ${ }^{\#} p<0.05$ versus $A \beta$ alone (one-way ANOVA and Fisher's LSD). In $\boldsymbol{D}$ and $\boldsymbol{E}$, the neurons were exposed to $25 \mu \mathrm{mA} \beta_{25-35}$ for $18 \mathrm{~h}$, and both $S$ phase (D) and apoptosis $(\boldsymbol{E})$ were assessed by FACS analysis. Values are the means \pm SEM of seven to nine determinations; ${ }^{*} p<0.05$ versus control (CTRL) and ${ }^{\#} p<0.05$ versus $A \beta$ alone (one-way ANOVA and Fisher's LSD). 
A

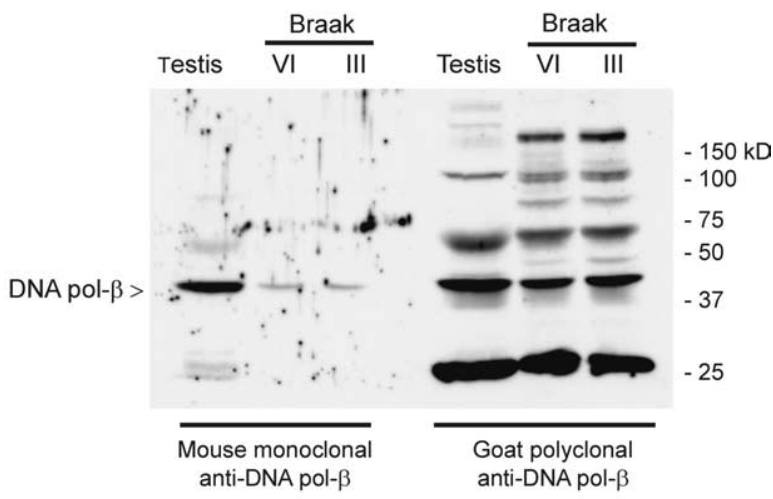

B

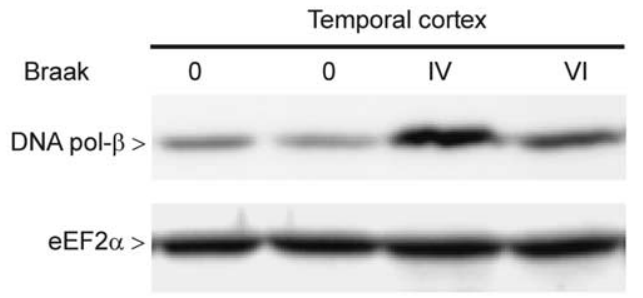

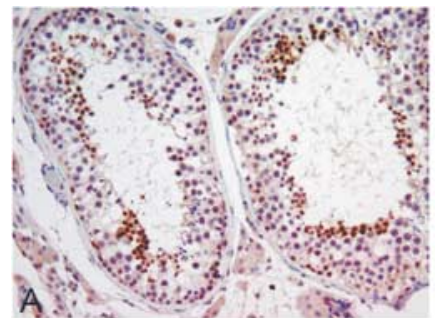
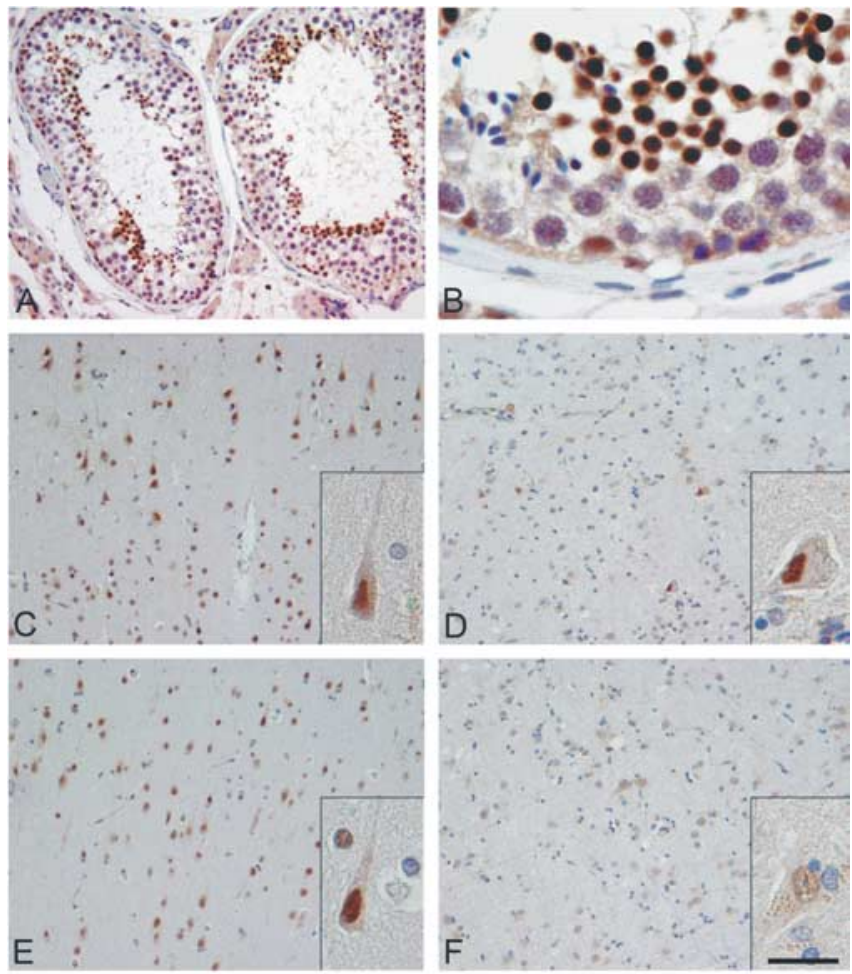

G

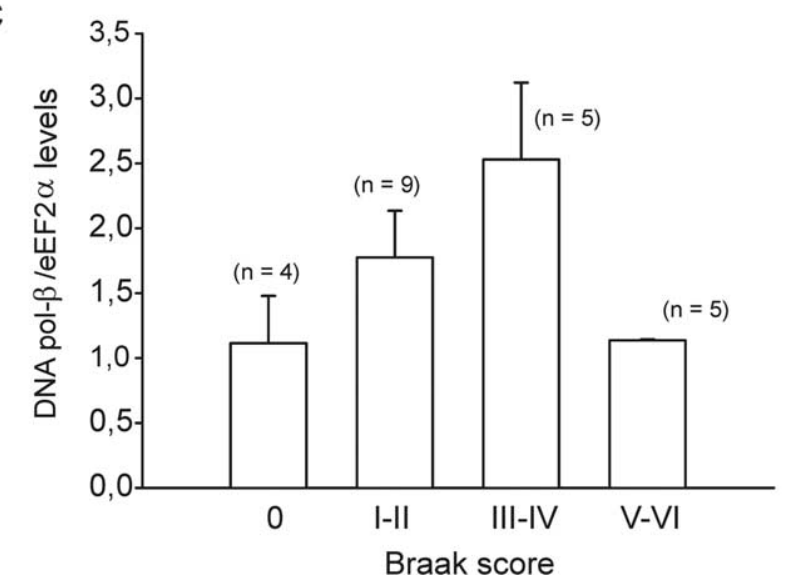

Figure 3. DNA pol- $\beta$ expression in human temporal cortex. $A$, DNA pol- $\beta$ band ( $39 \mathrm{kDa}$ ) in samples of human testes and temporal cortex (Braak score III and VI) assayed in parallel by two different anti-DNA pol- $\beta$ antibodies. $\boldsymbol{B}$, Representative immunoblot of DNA pol- $\beta$ in protein extracts of autoptic specimens from different Braak stages. The eEF2 $\alpha$ band is shown as a loading control. C, Densitometer analysis of DNA pol- $\beta$ expression levels from the indicated number of cases grouped according to the Braak score $(0,1 / I I, I I I / I V, V / V I)$. Values are the means \pm SEM of DNA pol- $\beta$ normalized against eEF $2 \alpha$.

throughout all layers of the temporal cortex and was most prominent in pyramidal neurons of layers III (Fig. 4C) and V (Fig. 4E). The intensities of nuclear staining varied in individual cases and between cases. Compared with nondemented controls (Fig. $4 C, E), \mathrm{AD}$ temporal cortex from late Braak stages (III/VI) showed a reduced number of DNA pol- $\beta$ immunoreactive neurons (Fig. $4 D, F)$, which often were stained intensely (Fig. $4 D$ ). Figure $4 G$ shows a semiquantitative immunoscoring of the number of neurons with immunoreactive nuclei per fixed area.

Expression of DNA pol- $\beta$ in astrocytes was very low. Immunoreactivity in astrocytes situated in layer I of the temporal cortex, both in terms of staining intensity and profile counts, was not

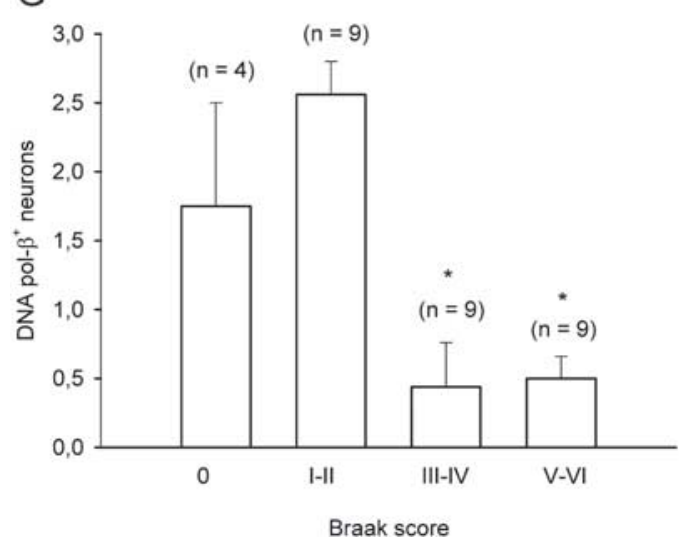

Figure 4. Immunohistochemical detection of DNA pol- $\beta$ in control and AD temporal cortex. $A$, Human testis served as a positive control for the immunohistochemical detection of DNA pol- $\beta$. $\boldsymbol{B}$, DNA pol- $\beta$ immunoreactivity is observed in nuclei of the spermatids in the seminiferous epithelium. $\boldsymbol{C}, \boldsymbol{E}$, In control temporal cortex (Brodmann area 21), DNA pol- $\beta$ immunoreactivity is observed in neurons (see insets). Immunoreactivity appears mainly in the nucleus of neurons in all layers ( $\boldsymbol{C}$, layer III/IV; $\boldsymbol{E}$, layer V). Shown is a nondemented control case with Braak stage Il and an immunoscore of 3. $\boldsymbol{D}, \boldsymbol{F}$, In AD temporal cortex DNA pol- $\beta$ immunoreactivity is observed in only a few neurons ( $\boldsymbol{D}$, layer III/IV; $\boldsymbol{F}$, layer V). Shown is an $\mathrm{AD}$ case with Braak stage $\mathrm{VI}$ and an immunoscore of 1. Scale bar: (in $\boldsymbol{F}$ ) $\boldsymbol{A}, \boldsymbol{C}-\boldsymbol{F}, 160 \mu \mathrm{m} ; \boldsymbol{B}$, insets, $40 \mu \mathrm{m}$. $\boldsymbol{G}$, Immunoreactive scores for DNA pol- $\beta$ in the indicated number of cases grouped according to Braak's staging. Values are the means \pm SEM of data obtained by semiquantitative scoring as follows: $0=$ no staining, $0.5=$ sporadic nuclear staining of neuronal cells, $1=<10 \%$ nuclear staining, $2=10-50 \%$ nuclear staining, and $3=>50 \%$ nuclear staining. ${ }^{*} p=0.001$ versus Braak I/II (Dunn's test after rank-based ANOVA).

different between Braak stages. DNA pol- $\beta^{+}$astrocytes were $2-5 \%$ of immunoreactive neurons, and the intensity of staining was consistently lower in astrocytes than in neurons.

DNA pol- $\beta$ immunoreactivity was investigated for its association with the classical neuropathological characteristics of $\mathrm{AD}$ (tangles and plaques). In cases with moderate AT8 (marker for hyperphosphorylated tau) immunoreactivity and high neuronal 


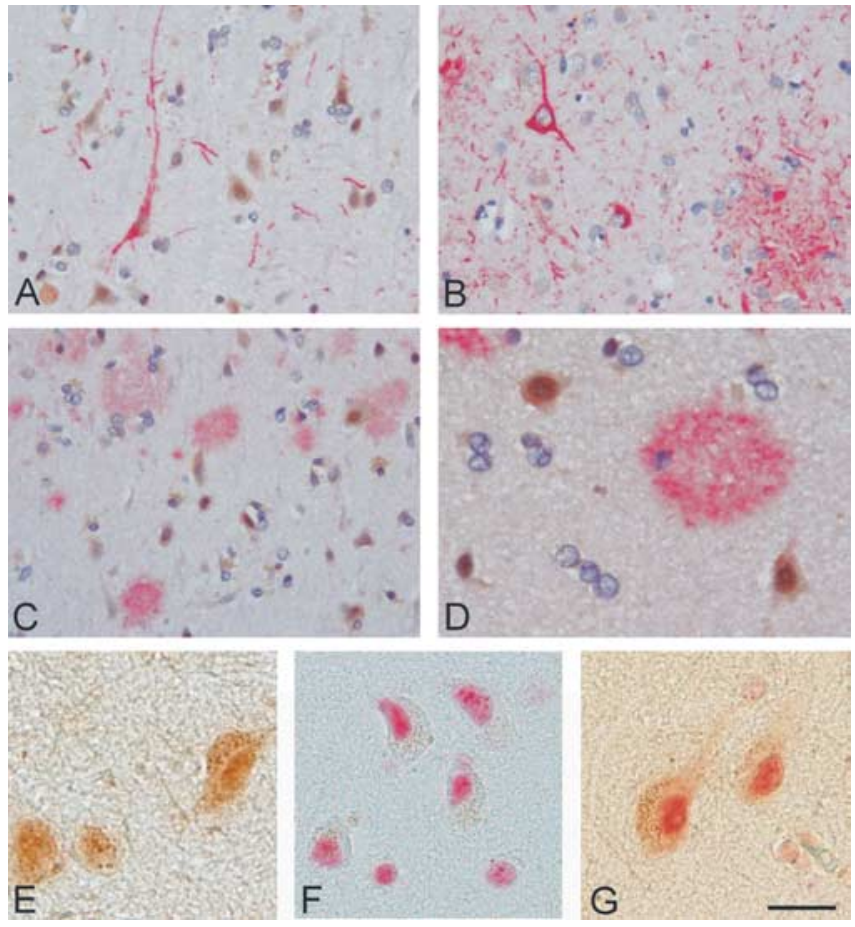

Figure 5. Immunohistochemical analysis of DNA pol- $\beta$, neurofibrillary changes, $A \beta$ deposits, and ppRb. $A, A$ case with only moderate neurofibrillary changes shows no strong association of nuclear DNA pol- $\beta$ staining (brown) with AT8 immunoreactivity (red). $\boldsymbol{B}$, A representative AD case with severe neurofibrillary changes. No immunoreactivity for DNA pol- $\beta$ is observed after double immunolabeling. $\boldsymbol{C}, \boldsymbol{D}, A$ nondemented control case with diffuse $A \beta$ plaques (4G8; red) and nuclear immunostaining for DNA pol- $\beta$ (brown). $E, F$, A case with strong immunoreactivity for DNA pol- $\beta(\boldsymbol{E})$ and ppRb $(\boldsymbol{F})$ shows a strong colocalization of these proteins in the nuclei of neuronal cells (G). Scale bar: (in G) $\boldsymbol{A}-\mathbf{C}, 40 \mu \mathrm{m} ; \boldsymbol{D}-\mathbf{G}, 20 \mu \mathrm{m}$.

DNA pol- $\beta$ immunoreactivity, no clear association between these markers was observed (Fig. $5 A$ ). In $\mathrm{AD}$ cases with severe neurofibrillary changes as observed by AT8 immunoreactive plaques and tangles, the DNA pol- $\beta$ immunoreactive signal was decreased or lost (Fig. $5 B$ ). DNA pol- $\beta$ neuronal immunoreactivity also could be observed in cases with moderate diffuse amyloid plaques (Fig. 5C,D). However, no clear association between the deposition of amyloid plaques and neuronal immunoreactivity for DNA pol- $\beta$ was observed throughout the different disease stages.

Because we hypothesize that DNA pol- $\beta$ is associated with the expression of cell cycle proteins in AD neurons, we compared the semiquantitative immunoreactive score for DNA pol- $\beta$ with the immunoreactive score of $\mathrm{ppRb}$. Immunoreactivity for $\mathrm{ppRb}$ in neurons throughout the different $\mathrm{AD}$ disease stages has been described before (Hoozemans et al., 2004). Comparison of the semiquantitative immunoreactivities in 31 different cases (Table 1 ) showed a significant positive correlation between DNA pol- $\beta$ and ppRb immunoreactivity levels (Fig. 6, top). There was instead a negative correlation between DNA pol- $\beta$ and AT8 immunoreactivity (Fig. 6, bottom). Double-immunohistochemistry performed in some AD cases showed a strong colocalization of DNA pol- $\beta$ and ppRb in neurons (Fig. $5 E, F$ ).

\section{Discussion}

Using pure cultures of rat cortical neurons, we have shown previously that $A \beta$ toxicity depends on the activation of an unscheduled cell cycle that proceeds until the S phase (Copani et al., 1999, 2002). An attractive possibility is that a pathological DNA repli-
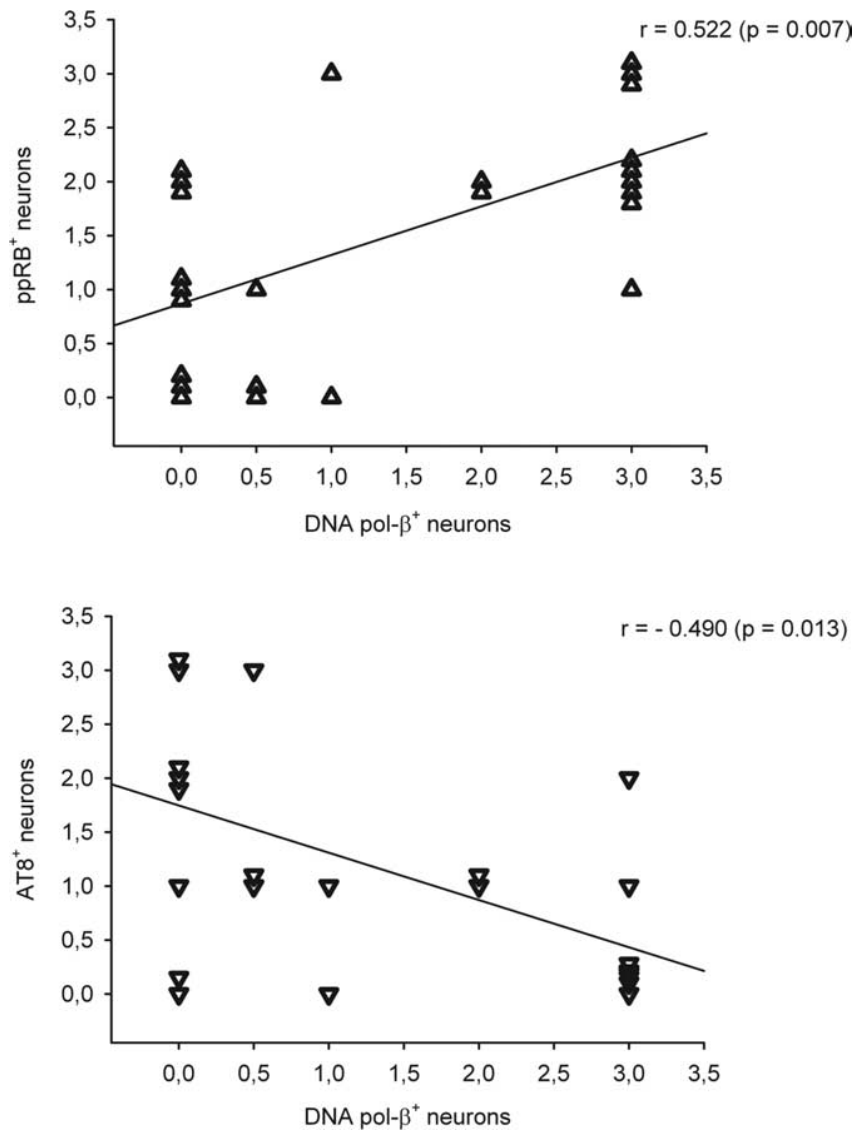

Figure 6. Correlation of DNA pol- $\beta$ immunoreactivity with $\mathrm{ppRb}$ (top) and AT8 (bottom). All Braak stages $(n=31)$ were included. Scatter plots show the number of immunoreactive neurons scored as described in Figure $4 G$. Solid lines represent the best fit correlation. The positive correlation coefficient $(r)$ indicates that DNA pol- $\beta$ and ppRb immunoreactivities tend to increase together. The negative correlation coefficient indicates that DNA pol $\beta$ immunoreactivity tends to decrease while AT8 staining increases.

cation performed by a noncanonical enzymatic machinery contributes to generate a death signal in neurons. DNA pol- $\beta$, which is an established DNA repair enzyme (Sobol et al., 1996), is involved somehow in this machinery, because its blockade reduces $S$ phase and apoptotic death induced by A $\beta$ (Copani et al., 2002). Here we demonstrate that DNA pol- $\beta$ is loaded into DNA replication forks in neurons that enter $\mathrm{S}$ phase in response to $\mathrm{A} \beta$. DNA pol- $\beta$ coimmunoprecipitated with $\mathrm{Cdc} 45$, a protein that is found exclusively at replication origins (Aparicio et al., 1999) and with DNA primase in relatively short nucleoprotein fragments (300 bp). This contrasted with DNA pol- $\delta$, which coimmunoprecipitated with Cdc45 and DNA primase only in longer nucleoprotein fragments (1000 bp). In addition, DNA pol- $\beta$ was found in immunoprecipitates at shorter times than DNA pol- $\delta$. These data suggest that DNA primase, pol- $\beta$, and pol- $\delta$ are loaded sequentially at the replication forks. Thus DNA pol- $\beta$ might substitute for the missing DNA pol- $\alpha$ in the abnormal machinery of DNA replication in $A \beta$-treated neurons. The use of methoxyamine indicated that APE-1 activity was not needed for DNA pol- $\beta$ loading at the replication forks, partially was required for DNA pol- $\delta$ loading, and contributed to the overall DNA synthesis and apoptotic death induced by $\mathrm{A} \beta$. Neuroprotection resulting from the inhibition of a DNA repair enzyme was unexpected and contrary to previous reports (Vasko et al., 2005). Because APE-1 initiates the process of DNA BER (Wong and Demple, 2004), we speculate that an efficient BER facilitates the loading of 
DNA pol- $\delta$ at the replication forks and, at the same time, allows it to reach the threshold for the death signal. Nevertheless, the component of DNA replication mediated by DNA pol- $\delta$ does not seem to be instrumental for neuronal death, because the DNA pol- $\alpha /$ pol- $\delta$ inhibitor aphidicolin reduced S phase, but not apoptotic death, in $\mathrm{A} \beta$-treated neurons. Inhibition of DNA pol- $\beta$ instead reduced both $S$ phase and death (Copani et al., 2002; present data). We propose that during neuronal cell cycle a de novo synthesis of DNA is allowed by the progressive loading of DNA primase, pol- $\beta$, and pol- $\delta$ at replication forks. The extension of DNA replication performed by DNA pol- $\beta$ is critical for the activation of a death signal that is mediated, at least in part, by the tumor suppressor protein p53 (Copani et al., 2002). Extension of replicated DNA becomes sufficient only in the presence of an efficient BER process, which is driven sequentially by APE- 1 and DNA pol- $\beta$ itself. DNA pol- $\delta$ is recruited at the replication forks after DNA pol- $\beta$ has been unloaded and the death signal has been triggered. The reduction of $S$ phase and apoptosis observed with $100 \mathrm{nM}$ of hydrogen peroxide in $\mathrm{A} \beta$-treated neurons is consistent with this scenario if one assumes that subtoxic concentrations of hydrogen peroxide might cause subtle DNA damage that is sufficient to saturate APE-1. However, we cannot exclude the possibility that protection by subtoxic concentrations of hydrogen peroxide is mediated by additional mechanisms that are relevant for cell survival (Guyton et al., 1996; Yu et al., 2006).

Our model predicts that concerted DNA replication and repair events determine whether and when neurons exposed to $\mathrm{A} \beta$ are committed to die. The high variability in the extent of DNA damage and the efficiency of DNA repair enzymes makes the timing of the death process unpredictable. This might be consistent with the calculation that cycling neurons take a long time to die in the AD brain (Busser et al., 1998; Yang et al., 2001, 2003) (for review, see Herrup et al., 2004).

The hypothesis that DNA pol- $\beta$ is involved causally in AD neurodegeneration is strengthened by the evidence that immunoblots from autoptic brain specimens showed a progressive increase of DNA pol- $\beta$ expression with the severity of the pathology from Braak 0 to III/IV. Protein expression declined in Braak V/VI cases, likely reflecting the severe neuronal loss. Accordingly, immunohistochemical analysis showed that DNA pol- $\beta$ was found mostly in neurons. Despite the high DNA pol- $\beta$ levels detected by immunoblotting, the number of DNA pol- $\beta^{+}$neurons was relatively low in samples from Braak III/IV cases. The most likely explanation is that the remaining neurons in the Braak III/IV temporal cortex express high levels of DNA pol- $\beta$, although other factors such as the relatively small number of cases or the different age and postmortem time of the individual cases selected for immunohistochemistry and Western blot analysis may contribute to the difference. The reduced total number of neurons in Braak V/VI samples explains why the overall expression of DNA pol- $\beta$ is low (see the immunoblots), although the percentage of immunopositive neurons is the same as in Braak III/IV samples.

Additional analysis showed that DNA pol- $\beta$ immunoreactivity did not correlate with $\mathrm{A} \beta$ plaques throughout the disease stages, consistent with the growing amount of evidence that small oligomers of $\mathrm{A} \beta$, rather than protein deposits, are neurotoxic (Kayed et al., 2003). Moreover, similarly to ppRb, DNA pol- $\beta$ could be detected in neurons from cases with minor AD-related neuropathology, whereas its expression decreased with increasing pathology. This suggests that DNA pol- $\beta$, like cell cycle proteins, is involved early in the pathogenesis of $\mathrm{AD}$ (Yang et al., 2003; Hoozemans et al., 2004).

The recruitment of DNA pol- $\beta$ for DNA synthesis in differ- entiated neurons is a remarkable example of how an unscheduled cell cycle may involve enzymes that normally function outside the cell division. The opposite is also true. The core proteins of the origin recognition complex, which normally initiate DNA replication during the cell cycle (Kelly and Brown, 2000), control dendritic branch formation and dendritic spine emergence in postmitotic neurons (Huang et al., 2005). These proteins might resume their typical function in cycling neurons, which therefore are deprived of a protein complex that is required for initiating dendritic spine formation during synaptic plasticity. That cell cycle activation in neurons is connected with the loss of synaptic function typical of the $\mathrm{AD}$ brain is an attractive hypothesis that warrants investigation.

Overall, our data reinforce the hypothesis that cell cycle reentry with DNA replication is critical to $\mathrm{AD}$ neurodegeneration. In addition, the unexpected finding that APE-1/Ref- 1 contributes to the overall DNA replication and apoptotic death induced by $\mathrm{A} \beta$ points to novel strategies for the inhibition of the neuronal cell cycle. In particular, the evidence that APE-1/Ref- 1 expression is increased in regions of neuronal injury in the $\mathrm{AD}$ brain (Tan et al., 1998) and also in A $\beta$-treated neurons (present data) strengthens the suggestion that APE-1 inhibitors, such as the anticancer drug methoxyamine (Madhusudan and Middleton, 2005), are potential neuroprotective agents in $\mathrm{AD}$.

\section{References}

Aparicio OM, Stout AM, Bell SP (1999) Differential assembly of Cdc45p and DNA polymerases at early and late origins of DNA replication. Proc Natl Acad Sci USA 96:9130-9135.

Becker EB, Bonni A (2004) Cell cycle regulation of neuronal apoptosis in development and disease. Progr Neurobiol 72:1-25.

Braak H, Braak E (1995) Staging of Alzheimer's disease-related neurofibrillary changes. Neurobiol Aging 16:271-278.

Busser J, Geldmacher DS, Herrup K (1998) Ectopic cell cycle proteins predict the sites of neuronal cell death in Alzheimer's disease brain. J Neurosci 18:2801-2807.

Copani A, Condorelli F, Caruso A, Vancheri C, Sala A, Giuffrida Stella AM, Canonico PL, Nicoletti F, Sortino MA (1999) Mitotic signaling by beta amyloid causes neuronal death. FASEB J 13:2225-2234.

Copani A, Uberti D, Sortimo MA, Bruno V, Nicoletti F, Memo M (2001) Activation of cell-cycle-associated proteins in neuronal death: a mandatory or dispensable path? Trends Neurosci 24:25-31.

Copani A, Sortino MA, Caricasole A, Chiechio S, Chisari M, Battaglia G, Giuffrida-Stella AM, Vancheri C, Nicoletti F (2002) Erratic expression of DNA polymerases by beta-amyloid causes neuronal death. FASEB J 16:2006-2008.

Giovanni A, Wirtz-Brugger F, Keramaris E, Slack R, Park DS (1999) Involvement of cell cycle elements, cyclin-dependent kinases, pRb, and E2F•DP, in $\beta$-amyloid-induced neuronal death. J Biol Chem 274:19011-19016.

Giovanni A, Keramaris E, Morris EJ, Hou ST, O’Hare M, Dyson N, Robertson GS, Slack RS, Park DS (2000) E2F1 mediates death of $\beta$-amyloid-treated cortical neurons in a manner independent of p53 and dependent on Bax and caspase 3. J Biol Chem 275:11553-11560.

Göhring F, Fackelmayer FO (1997) The scaffold/matrix attachment region binding protein hmRNP-U (SAF-A) is directly bound to chromosomal DNA in vivo: a chemical cross-linking study. Biochemistry 35:8276-8283.

Guyton KZ, Liu Y, Gorospe M, Xu Q, Holbrook NJ (1996) Activation of mitogen-activated protein kinase by $\mathrm{H}_{2} \mathrm{O}_{2}$. J Biol Chem 271:4138-4142.

Hardy J, Selkoe DJ (2002) The amyloid hypothesis of Alzheimer's disease: progress and problems on the road to therapeutics. Science 297:353-356.

Heim MM, Eberhardt W, Seeber S, Muller MR (2000) Differential modulation of chemosensitivity to alkylating agents and platinum compounds by DNA repair modulators in human lung cancer cell lines. J Cancer Res Clin Oncol 126:198-204.

Herrup K, Neve R, Ackerman SL, Copani A (2004) Divide and die: cell cycle events as triggers of nerve cell death. J Neurosci 24:9232-9239.

Hoozemans JJ, Veerhuis R, Rozemuller AJ, Arendt T, Eikelenboom P (2004) Neuronal COX-2 expression and phosphorylation of $\mathrm{pRb}$ precede $\mathrm{p} 38$ 
MAPK activation and neurofibrillary changes in AD temporal cortex. Neurobiol Dis 15:492-499.

Hoozemans JJ, Veerhuis R, Van Haastert ES, Rozemuller JM, Baas F, Eikelenboom P, Scheper W (2005) The unfolded protein response is activated in Alzheimer's disease. Acta Neuropathol (Berl) 110:165-172.

Huang Z, Zang K, Reichardt LF (2005) The origin recognition core complex regulates dendrite and spine development in postmitotic neurons. J Cell Biol 170:527-535.

Kayed R, Head E, Thompson JL, McIntire TM, Milton SC, Cotman CW, Glabe CG (2003) Common structure of soluble amyloid oligomers implies common mechanisms of pathogenesis. Science 300:486-489.

Kelly TJ, Brown GW (2000) Regulation of chromosome replication. Annu Rev Biochem 69:829-880.

Madhusudan S, Middleton MR (2005) The emerging role of DNA repair proteins as predictive, prognostic, and therapeutic targets in cancer. Cancer Treat Rev 31:603-617.

Mimura S, Masuda T, Matsui T, Takisawa H (2000) Central role for Cdc45 in establishing an initiation complex of DNA replication in Xenopus egg extracts. Genes Cells 5:439-452.

Pollok S, Stoepel J, Bauerschmidt C, Kremmer E, Nasheuer H-P (2003) Regulation of eukaryotic DNA replication at the initiation step. Biochem Soc Trans 31:266-269.

Reisberg B, Ferris SH, de Leon MJ, Crook T (1982) The global deterioration scale for assessment of primary degenerative dementia. Am J Psychiatry 139:1136-1139.

Siegel RL, Kalf GF (1982) DNA polymerase $\beta$ involvement in DNA endoreduplication in rat giant trophoblast cells. J Biol Chem 257:1785-1790.
Sobol R, Horton J, Kuhn R, Gu H, Prasad R, Rajewsky K, Wilson SH (1996) Requirement of mammalian DNA polymerase- $\beta$ in base-excision repair. Nature 379:183-186.

Sweasy J, Loeb L (1992) Mammalian DNA polymerase $\beta$ can substitute for DNA polymerase I during DNA replication in Escherichia coli. J Biol Chem 267:1407-1410.

Tan Z, Sun N, Schreiber SS (1998) Immunohistochemical localization of redox factor-1 (Ref-1) in Alzheimer's hippocampus. NeuroReport 9:2749-2752.

Vasko MR, Guo C, Kelley MR (2005) The multifunctional DNA repair/ redox enzyme Ape1/Ref-1 promotes survival of neurons after oxidative stress. DNA Repair (Amst) 4:367-379.

Wong D, Demple B (2004) Modulation of 5'-deoxyribose-5-phosphate lyase and DNA synthesis activities of mammalian DNA polymerase- $\beta$ by apurinic/apyrimidinic endonuclease. J Biol Chem 279:25368-25375.

Yamaguchi H, Haga C, Hirai S, Nakazato Y, Kosaka K (1990) Distinctive, rapid, and easy labeling of diffuse plaques in the Alzheimer brains by a new methenamine silver stain. Acta Neuropathol (Berl) 79:569-572.

Yang Y, Geldmacher DS, Herrup K (2001) DNA replication precedes neuronal cell death in Alzheimer's disease. J Neurosci 21:2661-2668.

Yang Y, Mufson EJ, Herrup K (2003) Neuronal cell death is preceded by cell cycle events at all stages of Alzheimer's disease. J Neurosci 23:2557-2563.

Yu HM, Zhi JL, Cui Y, Tang EH, Sun SN, Feng JQ, Chen PX (2006) Role of the JAK-STAT pathway in protection of hydrogen peroxide preconditioning against apoptosis induced by oxidative stress in PC12 cells. Apoptosis 11:931-941. 